\title{
ZARZĄDZANIE PŁYNNOŚCIĄ FINANSOWĄ NA PRZYKŁADZIE GRUPY KAPITAŁOWEJ BRANŻY HOTELARSKIEJ
}

Z a r y s t r e ś c i: Obecnie w warunkach rozwijającego się rynku kapitałowego, coraz częściej można zaobserwować złożone struktury gospodarcze. Jednostki gospodarcze działające na rynku, chcąc osiągnąć swoje cele, wchodzą w liczne i różnorodne związki z innymi podmiotami tworząc grupy kapitałowe. Uwzględniając wymienione aspekty, dokonano przeglądu dotychczasowego dorobku naukowego poświęconego tematyce grup kapitałowych. Jednym z motywów niniejszego artykułu jest pokazanie obrazu płynności finansowej ujawnionej w skonsolidowanych sprawozdaniach finansowych grup przedsiębiorstw. Głównym celem artykułu jest dokonanie analizy płynności finansowej wybranej grupy kapitałowej z branży hotelarskiej prowadzącej do wyodrębnienia czynników, które w największym stopniu wpływają na płynność finansową.

S ło w a k l u c z o w e: płynność finansowa, grupa kapitałowa, wskaźniki płynności

K 1 a s y f i k a j a J E L: L 21; G 32

\section{WSTĘP}

Rzeczywistość gospodarcza ciągnie za sobą różnego rodzaju przemiany strukturalne w zasadzie w każdym z sektorów gospodarki. Zmiany te mają wpływ na tworzenie nowych jednostek gospodarczych, jakimi są grupy kapitałowe. Specyfika tego złożonego organizmu gospodarczego powoduje potrzebę szerszego spojrzenia m.in. na wyniki osiągane nie tylko przez pojedyncze

\footnotetext{
* Adres do korespondencji: Beata Czuba-Kulisińska, Politechnika Częstochowska, Wydział Zarządzania, aleja Armii Krajowej 19, 42-200 Częstochowa, e-mail: beataczuba@op.pl; Karolina Gałązka, Politechnika Częstochowska, Wydział Zarządzania, aleja Armii Krajowej 19, 42-200 Częstochowa.
} 
niezależne przedsiębiorstwa, ale także na wyniki osiągane przez grupę przedsię biorstw ocenioną całościowo. Analiza płynności finansowej to nie tylko ujęcie statystyczne. W przedstawionej analizie finansowej grupy kapitałowej, duże znaczenie ma badanie płynności na podstawie rachunku przepływów pieniężnych. Sprawozdanie takie daje wiele informacji, odmiennych od tych zawartych w bilansie, pozwalając na określenie źródła pochodzenia środków pieniężnych, a także kierunki ich wydatkowania.

Jednym $\mathrm{z}$ istotnych obszarów zmian zachodzących w polskiej gospodarce są przekształcenia jej struktury podmiotowej oraz związane z nimi intensywne procesy konsolidacji organizacyjnej i finansowej przedsiębiorstw. Efektem tych przeobrażeń jest powstanie licznych grup kapitałowych, które w warunkach polskich są strukturą stosunkowo młodą, a jednocześnie już powszechną i dynamicznie się rozwijającą [Trocki, 2004, s. 42].

Przyczyny i cele powołania grup kapitałowych mogą być różnorodne, tak jak różne są podmioty wchodzące w ich skład. Jednym z najważniejszych celów wymienianych w literaturze są trwanie i rozwój przedsiębiorstw. Staje się to możliwe wtedy, gdy przedsiębiorstwa będą konkurencyjne na rynku. Konkurencyjność umożliwia rozwój a to oznacza, że wszystkie podmioty wchodzące w skład grupy mają możliwość realizacji swoich celów: ekonomicznych, rynkowych, kierowniczych, operacyjnych i finansowych [Trocki, 2004, s. 42].

\section{ISTOTA I RODZAJE GRUP KAPITAŁOWYCH}

W literaturze dotyczącej grup kapitałowych, obecnie istnieje bardzo wiele dylematów terminologicznych dotyczących próby zdefiniowania tego pojęcia. Terminologia grup kapitałowych kształtowała się dość spontanicznie, co w rezultacie doprowadziło do braku spójnego i logicznego definiowania. W praktyce stosowane są często sprzeczne pojęcia zaczerpnięte $\mathrm{z}$ różnych dziedzin wiedzy, tradycji językowych oraz wynikające $z$ wielu doświadczeń praktycznych. Jak zauważa J. Chadam, zainteresowanie grupami kapitałowymi było i jest nadal aktualnym tematem wielu prac badawczych w ostatnim okresie. Zwraca on również uwagę na fakt, iż w polskim ustawodawstwie problematyka grup kapitałowych nie została dotychczas uregulowana kompleksowo. Dlatego też, w literaturze przedmiotu można spotkać pojęcie grupy kapitałowej utożsamiane $\mathrm{z}$ pojęciem holdingu [Chadam, 2002, s. 66].

Jak wskazuje A.Szewc-Rogalska jednoznaczne zdefiniowanie grup kapitałowych jest zadaniem niezmiernie trudnym. Nie ma bowiem spójnego, logicznego systemu terminologicznego opisującego struktury kapitałowe. $\mathrm{W}$ praktyce stosowane są często odmienne pojęcia zaczerpnięte $\mathrm{z}$ różnych dziedzin wiedzy i tradycji językowych oraz wynikające $\mathrm{z}$ różnych doświadczeń 
praktycznych [Szewc-Rogalska, s. 654]. Tabela 1 zawiera zestawienie wybranych definicji grup kapitałowych.

Tabela 1. Zestawienie wybranych definicji grup kapitałowych

\begin{tabular}{|c|c|c|}
\hline Lp. & Autor / Rok & Treść definicji \\
\hline 1. & $\begin{array}{l}\text { M. Romanow- } \\
\text { ska, M. Trocki, } \\
\text { B. Wawrzy- } \\
\text { niak, } \\
2002\end{array}$ & $\begin{array}{l}\text { Grupakapitałowato,zespółsamodzielnychpodwzględemprawnymprzedsiębiorstw, } \\
\text { stworzonych do realizacjiwspólnych celówgospodarczych, powiązanych kapitałowo } \\
\text { i ewentualnie kontraktowo, w sposób umożliwiający aktywne współdziałanie [Ro- } \\
\text { manowska, Trocki, Wawrzyniak, } \\
\text { 2002, s. } 128 \text { ]. }\end{array}$ \\
\hline 2. & $\begin{array}{l}\text { Z. Kreft, } \\
2004\end{array}$ & $\begin{array}{l}\text { Autor stwierdza, iż w Polsce obecnie dopiero zaczynamy uczyć się holdingów. } \\
\text { Stanowią nową strukturę, gdyż mają bardzo krótką historię i to właśnie stąd po- } \\
\text { wstaje wiele problemów teoretycznych jak i wdrożeniowych - aplikacyjnych [Kreft, } \\
\text { 2004, s. 28]. }\end{array}$ \\
\hline 3. & $\begin{array}{l}\text { J. Chadam, } \\
2002\end{array}$ & $\begin{array}{l}\text { Wartykule poświęconym spółkom zależnym, stara się wprowadzić rozróżnienie po- } \\
\text { jęć holding i grupa kapitałowa. Przyjmuje on, iż holding oznacza spółkę nadrzędną } \\
\text { co stanowi dokładne tłumaczenie zjęzyka angielskiego. Natomiast pojęcie grupy ka- } \\
\text { pitałowej odnosi się do całości powiązanej struktury przedsiębiorstwa nadrzędnego } \\
\text { i spółek mu podległych [Chadam, 2002, s. 66]. }\end{array}$ \\
\hline 4. & $\begin{array}{l}\text { W. Szumiele- } \\
\text { wicz, } 2009\end{array}$ & $\begin{array}{l}\text { Grupa kapitałowa definiowana jako zespół samodzielnych pod względem praw- } \\
\text { nym przedsiębiorstw, stworzona do realizacji wspólnych celów gospodarczych } \\
\text { powiazanych } \\
\text { kapitałowo i ewentualnie kontraktowo w sposób umożliwiajacy ak- } \\
\text { tywne współdziałanie, jest struktura działalności gospodarczej wy- } \\
\text { magającą odpowiedniego instrumentarium, diagnozowania, kształto- } \\
\text { wania i oceny systemu zarządzania. Składają się na niego obszary } \\
\text { w których dochodzi do współdziałania pomiędzy spółkami-uczestnikami grupy } \\
\text { [Szumielewicz, } 2009 \text { s. 11]. }\end{array}$ \\
\hline 5. & $\begin{array}{l}\text { B. Kaczmarek, } \\
\text { B. Glinkowska, } \\
2012\end{array}$ & $\begin{array}{l}\text { Grupa kapitałowa stanowi koncentrację kapitału w celu np. realizacji wspólnych } \\
\text { zadań gospodarczych czy też przewagi konkurencyjnej i dominacji rynkowej, jej } \\
\text { istota polega na połączeniu wysiłków finansowych wspólników i realizacji określo- } \\
\text { nego przedsięwzięcia, przekraczającego możliwości finansowe każdego z nich z } \\
\text { osobna [Kaczmarek, Glinkowska, 2012, s. 28]. }\end{array}$ \\
\hline
\end{tabular}

Źródło: opracowanie własne na podstawie przeglądu literatury

Zauważyć należy, że funkcjonujące w dzisiejszej rzeczywistości grupy kapitałowe to organizmy, których struktura skupia wiele podmiotów na wielu szczeblach, powiązanych kapitałowo oraz poza kapitałowo [Bąk, 2014, s. 9 ].

E. Piątek i w jednej z publikacji pisze, iż odpowiednikiem grupy kapitałowej w zachodnich gospodarkach jest holding [Piątek, 2007, s. 25]. W dalszej części publikacji charakteryzując główne typy grup kapitałowych, wyróżnia holding operacyjny, strategiczny i finansowy. Występuję zatem wyraźna sugestia zamiennego traktowania pojęć. 
Obecnie możemy zaobserwować różnorodne formy organizowania się grup przedsiębiorstw. W praktyce spotykamy się z dużą ilością rodzajów grup kapitałowych, wyodrębnionych na podstawie rożnych kryteriów. Potwierdzenie mnogości holdingów, znajduje się w publikacji Z. Krefta [2004, s. 32].

Odwołuje się on do najstarszej typologii holdingów zamieszczonej w polskiej literaturze przez L. Steckiego. Ten wybitny autor wyodrębnił na kilkudziesięciu stronach kryteria i wynikające z nich klasyfikacje, z szerokim omówieniem specyfiki prezentowanych typów holdingów występujących na świecie. Niewątpliwie typologia ta jest cenna poznawczo i może przerażać mnogością wyodrębnionych form. Z. Kreft stara się odpowiedzieć na pytanie: czy nie można dokonać pewnego uogólnienia i agregacji, wyodrębniając te kryteria, które zarówno dla teoretyków, jak i praktyków mają kluczowe znaczenie? Odpowiedź na to pytanie jest twierdząca, co jednocześnie czyni klasyfikację mniej drobiazgową i zbliża teorię do rozwiązań stosowanych w praktyce [Kreft, 2004, s. 32 ] .

Tabela 1 stanowi potwierdzenie tezy, iż pojęcie grupy kapitałowej jest bardzo szerokie. Obejmuje różnorodne rozwiązania organizacyjne, a charakter tych rozwiązań ma decydujący wpływ na formy i sposoby zarządzania grupą. Częstotliwość występowania poszczególnych typów grup jest zróżnicowana. Przeprowadzone badania literaturowe wskazują, iż najczęściej spotykanymi grupami przedsiębiorstw na świecie są: holding operacyjny, holding strategiczny/zarządczy oraz holding finansowy. Po dokonaniu analizy podstawowych form grup kapitałowych należałoby zdać sobie pytanie: Która z nich jest najlepsza? Biorąc pod uwagę wady i zalety poszczególnych holdingów, ale również potencjalne korzyści wynikające $\mathrm{z}$ udziału $\mathrm{w}$ danej grupie przedsiębiorstw, najbardziej interesującą formą, według opinii autorek jest holding finansowy. Zapewne, za tym faktem przemawia argument, iż jest on bardzo podobny do jakże modnych $\mathrm{w}$ dzisiejszych czasach funduszy inwestycyjnych. $\mathrm{Z}$ drugiej strony jednak, fundusze pociągają za sobą pewne ryzyko.

Obecnie podmioty gospodarcze działające w postaci grup kapitałowych można spotkać prawie na całym świecie. Jednak uregulowania prawne dotyczące problemu ich funkcjonowania różnią się znacznie w poszczególnych krajach. W tabeli 2 przedstawiono dynamikę powstawania grup kapitałowych na przestrzeni lat 2010 do 2014.

Tabela 2. Grupy kapitałowe w Polsce w latach 2010 - 2014

\begin{tabular}{|l|l|l|l|l|l|l|}
\hline Lp. & Wyszczególnienie & 2010 & 2011 & 2012 & 2013 & 2014 \\
\hline 1. & $\begin{array}{l}\text { Grupy kapitałowe w Polsce } \\
\text { (ilość) }\end{array}$ & 1806 & 1951 & 2049 & 2039 & 2040 \\
\hline
\end{tabular}

Źródło: opracowanie własne oparte o dane z GUS 
Nie ulega wątpliwości fakt, iż w latach 2010 - 2012 nastąpił przyrost ilości grup kapitałowych. Natomiast od roku 2012 średnia liczba grup kapitałowych w Polsce kształtuje się na poziomie około 2040 szt.

\section{ZARZĄDZANIE PŁYNNOŚCIĄ FINANSOWA W GRUPACH KAPITAŁOWYCH}

Chcąc ocenić ryzyko finansowe należy rozważyć dwa aspekty działalności jednostki gospodarczej, tj.: płynność finansową przedsiębiorstwa oraz jego zadłużenie. Częstą formą finansowania bieżącej działalności jest wykorzystanie zobowiązań krótkoterminowych, na które najczęściej składają się zobowiązania $\mathrm{z}$ tytułu zaciągniętych kredytów bankowych oraz zobowiązania wobec dostawców z tytułu zakupów dokonywanych z odroczonym terminem płatności. Korzystne do pewnego momentu zwiększanie zobowiązań krótkoterminowych może powodować, przy zbyt dużym spiętrzeniu płatności, zatory płatnicze.

Kontrolowanie i utrzymywanie płynności finansowej jednostek, w tym również grup kapitałowych polega zatem na odpowiednim sterowaniu poziomem zobowiązań krótkoterminowych i służących ich regulowaniu płynnych środków obrotowych. Jest to jedne z najważniejszych zadań dyrektora finansowego [Machała, 2008, s. 385]. E. Nowak pisze, iż płynność finansowa jest oceniana na podstawie relacji między aktywami obrotowymi o różnym stopniu płynności a zobowiązaniami krótkoterminowymi [Nowak, 2010, s. 194]. Stopień płynności danego składnika aktywów zależy od tego, jak szybko może on zostać zamieniony na gotówkę bez ponoszenia znacznych strat. Zarządzanie płynnością polega zatem na synchronizowaniu w celu uniknięcia technicznej niewypłacalności roszczeń wierzycieli z wpływami wynikającymi z przekształcenia aktywów w gotówkę i wpływami gotówki z innych tytułów. (...) Główny problem polega na tym, czy podmiot jest w stanie wypracować wystarczającą ilość gotówki, aby zapłacić swoim dostawcom i wierzycielom? [Groppelli, Nikbakht, 1999, s. 367] .

Aby móc swobodnie działać, przedsiębiorstwa jak też grupy kapitałowe muszą utrzymywać płynność finansową, czyli zdolność warunkującą przetrwanie [Pomykalska, Pomykalski, 2007, s. 67]. Najczęściej przez płynność rozumie się zdolność do terminowego regulowania zobowiązań bieżących. Często jednak mylone jest to pojęcie z wypłacalnością, która oznacza zdolność do pokrycia łącznych długów posiadanym majątkiem [Sierpińska, Jachna, 2004, s. 146]. Badanie płynności finansowej jest kluczowe z punktu widzenia oceny możliwości przetrwania podmiotu w krótkim okresie. Najpowszechniej wykorzystywane do tego wskaźniki to wskaźnik płynności bieżącej, który informuje o zdolności przedsiębiorstwa do regulowania zobowiązań w oparciu o aktywa obrotowe. 
Obliczany jest on następująco:

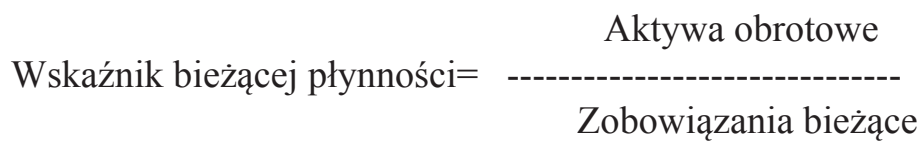

Jest to podstawowy wskaźnik płynności finansowej, ukazujący stopień pokrycia zobowiązań bieżących aktywami obrotowymi. Przyjęta przez banki i podawana w literaturze jego wzorcowa wartość mieści się w przedziale 1,3-2 [Sierpińska, Jachna, 2004, s. 146 ]. Zbyt wysoka ale i również zbyt niska wartość tego wskaźnika, powoduje negatywne konsekwencje dla przedsiębiorcy. Niski poziom może oznaczać, iż firma ma lub w najbliższej przyszłości będzie miała, kłopoty z terminowym regulowaniem zobowiązań. Natomiast zbyt wysoki poziom tego wskaźnika świadczy o tym, że przedsiębiorstwo niepotrzebnie przechowuje zbyt dużo środków finansowych, które mogłoby wykorzystać na inwestycje, utrzymuje nadmierne zapasy lub posiada trudno ściągalne należności. Niewątpliwie wadą wskaźnika bieżącej płynności jest fakt, iż w aktywach obrotowych znajdują się zapasy oraz rozliczenia międzyokresowe, które jako że są stosunkowo mało płynne, słabo zabezpieczają płynność finansową podmiotu. Dlatego też wskaźnik ten uzupełnia się o wskaźnik szybkiej płynności. Różni się on od powyższego tym, że z aktywów obrotowych eliminowane są mało płynne zapasy i rozliczenia międzyokresowe

Aktywa obrotowe-zapasy-krótkoterm. Rozl.

Wskaźnik płynności szybkiej =

Zobowiązania bieżące

Wskaźnik ten pokazuje stopień pokrycia zobowiązań krótkoterminowych aktywami o dużym stopniu płynności. Wskaźnik szybki wynoszący 1 uważany jest za satysfakcjonujący i przedsiębiorstwo jest w stanie pokryć wszystkie swoje zobowiązania przy pomocy płynnych aktywów finansowych. Oprócz wymienionych wskaźników w analizach płynności finansowej wykorzystuje się również wskaźnik środków pieniężnych. Ustala się go według formuły:

Inwestycje krótkoterminowe

Wskaźnik środków pieniężnych=

\section{Zobowiązania bieżące}

W ten sposób otrzymuje się wskaźnik określający relację najbardziej płynnych aktywów - środków pieniężnych do zobowiązań krótkoterminowych. Wskaźnik ten pozwala określić, jaką część zobowiązań bieżących można bez- 
zwłocznie spłacić, nie czekając na spłaty należności. Środki pieniężne przedsiębiorstwa to środki pieniężne w kasie i środki pieniężne na rachunkach. Poziom tego wskaźnika określają zasady zarządzania środkami pieniężnymi. W literaturze przyjmuje się, że zasoby środków pieniężnych powinny być ograniczone do niezbędnego minimum. Wzorcowy wskaźnik wypłacalności środków pieniężnych wynosi 20\% [Pomykalska, Pomykalski, 2007, s. 67]

Wymienione wskaźniki należą do grupy tzw. statycznych wskaźników oceny płynności finansowej. Są one oparte na danych bilansowych, które odzwierciedlają stan majątku obrotowego na ściśle określony moment. Szacując wartości wyżej omówionych wskaźników, nie uwzględnia się strumieni pieniężnych generowanych przez przedsiębiorstwo, dzięki którym spłata zadłużenia staje się możliwa. Dlatego też, w celu pełniejszej oceny płynności finansowej wykorzystuje się tzw. dynamiczne wskaźniki płynności finansowej, które oparte są na przepływach pieniężnych.

Wskaźnik wydajności gotówkowej sprzedaży =

przepływy z działalności operacyjnej $\mathrm{x} 100$

razem przychody ze sprzedaży

Wskaźnik wydajności gotówkowej sprzedaży przedstawia stopień wygenerowanej gotówki z działalności operacyjnej przez przychody ze sprzedaży. Wyższa wartość tego wskaźnika oznacza więcej gotówki zrealizowanej ze sprzedaży i wyższe bezpieczeństwo utrzymania płynności finansowej.

Wskaźnik wystarczalności gotówki operacyjnej na spłatę zobowiązań ogółem $=$

przepływy z działalności operacyjnej

zobowiązania ogółem $\mathrm{x} 100$

Wskaźnik wystarczalności gotówki operacyjnej na spłatę długów ogółem informuje o procentowym udziale przepływów gotówkowych z działalności operacyjnej pokrywających zobowiązania ogółem. Otrzymany wynik odpowiada na pytanie: jaki procent zobowiązań ogółem pokrywają gotówkowe przepływy z działalności operacyjnej? Wyższa wartość tego wskaźnika informuje o większym zabezpieczeniu zobowiązań ogółem przez gotówkowe przepływy z działalności operacyjnej. 
Wskaźnik zdolności do generowania środków pieniężnych z działalności operacyjnej $=$

przepływy z działalności operacyjnej

przepływy z działalności operacyjnej + wpływy z działalności inwestycyjnej + wpływy z działalności finansowej

Wskaźnik zdolności do generowania środków pieniężnych z działalności operacyjnej informuje, jaki jest udział przepływów pieniężnych z działalności operacyjnej w relacji do wpływów z pozostałych działalności (inwestycyjnej i finansowej). Wyższa wartość tego wskaźnika świadczy o większym wykorzystaniu podstawowej działalności operacyjnej do generowania środków pieniężnych. Nie ma określonego poziomu, jaki powinien ten wskaźnik osiągać. Jednakże to działalność operacyjna jest tą działalnością, z której przede wszystkim powinny być generowane środki pieniężne. Jeżeli występują znaczne jednorazowe odstępstwa, od tej zasady należy zbadać źródła generowanych przychodów i wyjaśnić przyczyny, czy były to jednorazowe zdarzenia i czym były podyktowane.

\section{CHARAKTERYSTYKA DZIAŁALNOŚCI WYBRANEJ GRUPY KAPITAŁOWEJ}

Polskie Biuro Podróży Orbis powstało we Lwowie w 1920 roku. Założyciele chcieli stworzyć biuro podróży o międzynarodowym standardzie obsługi. Instytucję, która byłaby oknem na świat dla obywateli nowo odrodzonego państwa polskiego.

Wraz z rozwojem usług hotelarskich i obsługi podróży, Orbis a w 1991 roku Przedsiębiorstwo Państwowe Orbis przekształcono w jednoosobową spółkę Skarbu Państwa. W lipcu 1993 roku z dotychczasowej struktury wyodrębnione zostały dwie spółki: Orbis Travel oraz Orbis Transport, w których Orbis S.A. posiada większościowe pakiety udziałów. W dniu 27 czerwca 1997 roku Walne Zgromadzenie Akcjonariuszy podjęło decyzję o upublicznieniu akcji Orbis SA Od 15 listopada 1997 akcje Orbis SA są notowane na Warszawskiej Giełdzie Papierów Wartościowych. W 1999 roku udział Skarbu Państwa w akcjonariacie Spółki spadł poniżej 50\%. W sierpniu 2000 roku nastąpił ostatni etap prywatyzacji, Orbis SA pozyskał partnera strategicznego - Accor, jedną z największych międzynarodowych grup w dziedzinie turystyki, biur podróży i usług dla przedsiębiorstw; europejskiego lidera na rynku hotelowym. W 2010 roku ogłoszono nową strategię dotyczącą reorganizacji spółki i skupienia się wyłącznie na działalności hotelowej oraz sprzedaży pozostałych biznesów: 
Orbis Travel (2010 r.)

Orbis Casino (2011 r.)

Orbis Transport (2013 r.)

7 stycznia 2015 roku Orbis podpisał ze swoim partnerem strategicznym Accor i podmiotami z jego grupy kapitałowej umowy dotyczące zakupu sieci 38 hoteli w Europie Wschodniej oraz zawarł Generalną Umowę Licencyjną (Master License Agreement). Tym samym Orbis umocnił swoją pozycję lidera branży hotelowej w Europie Wschodniej oraz został wyłącznym licencjodawcą wszystkich marek Accoru w 16 krajach regionu. Grupa Hotelowa Orbis to dziś największa sieć hoteli w Polsce i Europie Wschodniej, która oferuje niemal 19 tysięcy pokoi w ponad 100 hotelach. Orbis S.A. jest jednostką dominującą dla Grupy Kapitałowej Orbis.

\section{ANALIZA PŁYNNOŚCI FINANSOWEJ WYBRANYCH GRUP KAPITAŁOWYCH}

Analizując zestawienie statystycznych wskaźników płynności finansowej wybranej grupy kapitałowej branży hotelarskiej stwierdzić należy, że badana grupa nie powinna mieć problemów ze swobodnym działaniem w najbliższej przyszłości. Wskaźnik bieżącej płynności finansowej jako podstawowy miernik płynności finansowej na przełomie lat 2013 - 2015 mieści się prawie w każdym roku w granicach wielkości wzorcowych tj. w przedziale 1,3-2 (tabela 3.). W latach 2013 i 2014 grupa nieznacznie przekroczyła wielkość wzorcową niepotrzebnie przechowując zbyt dużą ilość środków finansowych.

Tabela 3. Zestawienie statycznych wskaźników płynności finansowej

\begin{tabular}{|l|l|c|c|c|}
\hline \multirow{2}{*}{ Lp. } & \multirow{2}{*}{ Wyszczególnienie } & \multicolumn{3}{|c|}{ ORBIS } \\
\cline { 3 - 5 } & & $\mathbf{2 0 1 3}$ & $\mathbf{2 0 1 4}$ & $\mathbf{2 0 1 5}$ \\
\hline 1. & Wskaźnik bieżącej płynności & 2,59 & 2,48 & 1,51 \\
\hline 2. & Wskaźnik szybkiej płynności & 2,54 & 2,45 & 1,49 \\
\hline 3. & Wskaźnik środków pienieżnych & 2,19 & 2,05 & 1,14 \\
\hline
\end{tabular}

Źródło: Opracowanie własne na podstawie sprawozdań finansowych wybranej grupy kapitałowej w latach 2013 - 2015

Wskaźnik szybkiej płynności finansowej tj. po wyeliminowaniu z aktywów obrotowych mało płynnych zapasów oraz rozliczeń międzyokresowych, pokazujący stopień pokrycia zobowiązań krótkoterminowych aktywami o dużym stopniu płynności w badanym okresie wykazywał poziom powyżej 1, uważany za satysfakcjonujący i przedsiębiorstwo jest w stanie pokryć wszystkie swoje zobowiązania przy pomocy płynnych aktywów finansowych. 
Ostatnim z badanych wskaźników statycznej płynności finansowej jest wskaźnik środków pieniężnych, który w analizowanej grupie kapitałowej znacznie przekracza wzorcowy wskaźnik wypłacalności środków pieniężnych na poziomie $20 \%(0,2)$, co ma uzasadnienie w kredytach zaciągniętych na działalność inwestycyjną, a tylko chwilowo środki te zawyżają wskaźnik środków pieniężnych.

Na przełomie lat 2013 - 2015 badana grupa kapitałowa osiągała wskaźnik wydajności gotówkowej sprzedaży na poziomie $23 \%$, czym wyższy analizowany wskaźnik tym więcej gotówki zrealizowanej ze sprzedaży i wyższe bezpieczeństwo utrzymania płynności finansowej (tabela 4).

Tabela 4. Zestawienie dynamicznych wskaźników płynności finansowej [w \%]

\begin{tabular}{|l|l|c|c|c|}
\hline \multirow{2}{*}{ Lp. } & \multirow{2}{*}{ Wyszczególnienie } & \multicolumn{3}{|c|}{ ORBIS } \\
\cline { 3 - 5 } 1. & $\begin{array}{l}\text { Wskaźnik wydajności } \\
\text { gotówkowej sprzedaży }\end{array}$ & 2013 & $\mathbf{2 0 1 4}$ & 2015 \\
\hline & $\begin{array}{l}\text { Wskaźnik wystarczalności } \\
\text { gotówki operacyjnej na spłatę } \\
\text { zobowiazzań ogółem }\end{array}$ & 27 & 23 \\
\hline & $\begin{array}{l}\text { Wskaźnik zdolności do } \\
\text { generowania środków pieniezżnych } \\
\text { z działalności operacyjnej }\end{array}$ & 130 & 132 & 42 \\
\hline 3
\end{tabular}

Źródło: Opracowanie własne na podstawie sprawozdań finansowych wybranej grupy kapitałowej w latach $2013-2015$

Wskaźnik wystarczalności gotówki operacyjnej na spłatę zobowiązań ogółem $\mathrm{w}$ analizowanym okresie był na poziomie od 130 - 40\%, co oznacza, że zobowiązania ogółem w latach 2013 i 2014 były w pełni pokryte gotówkowymi przepływami z działalności operacyjnej. W roku 2015 wskaźnik ten jedynie osiągnął poziom $42 \%$.

Ostatnim z analizowanych wskaźników dynamicznej płynności finansowej jest wskaźnik zdolności do generowania środków pieniężnych z działalności operacyjnej, który w badanej grupie kapitałowej mieścił się w okresie 2013 3015 na poziomie od $72-27 \%$. Z uwagi na fakt, iż to działalność operacyjna jest tą działalnością z której przede wszystkim powinny być generowane środki pieniężne, należałoby dokładniej przeanalizować i wyjaśnić przyczyny, czy były to tylko jednorazowe zdarzenia i czym były podyktowane, że w roku 2015 wskaźnik ten był już na poziomie $27 \%$. 


\section{PODSUMOWANIE}

Ocena efektywności systemów gospodarczych jest zagadnieniem złożonym, ale też bardzo ważnym $\mathrm{w}$ analizie mechanizmów maksymalizowania produkcji i dobrobytu społecznego. Uzyskanie wiarygodnych i kompleksowych wyników takiej oceny pozwoliłoby na poprawę skuteczności funkcjonowania systemów. Szczególnego znaczenia nabiera ona w podmiotach, takich jak grupy kapitałowe gdzie ścierają się interesy różnych jednostek. $Z$ drugiej strony podmioty w ramach grupy kapitałowej można traktować, jako swojego rodzaju „,entra zysków", których funkcjonowanie powinno przyczyniać się do wzrostu efektywności całości.

Podsumowując można stwierdzić, iż łączenie się przedsiębiorstw w Polsce jest naturalnym zachowaniem, wymuszonym przez rynek i otoczenie. Dokonane obserwacje pozwalają na stwierdzenie, że zjawisko to może okazać się główną metodą odzyskiwania sprawności, produktywności, konkurencyjności gospodarki a także wpływa na utrzymanie płynności finansowej. Szczególną przesłanką analizy sprawozdań finansowych skonsolidowanych może być również to, że grupy kapitałowe stają się jednym z głównych elementów rzeczywistości gospodarczej. Uwzględniając fakt, iż powstały one z potrzeb poszukiwania nowych dróg rozwoju podmiotów i nowych metod zarządzania działalnością gospodarczą, niezbędne staje się podejmowanie próby oceny efektów tych poszukiwań. Efekty dokonywanych połączeń przedsiębiorstw niekoniecznie szybko się ujawniają i niekoniecznie są widoczne wprost w księgach rachunkowych analizowanych podmiotów.

\section{LITERATURA}

Bąk B. (2014) Rola powiazań w grupie kapitałowej oraz ich wpływ na zarzadzanie grupa na przyktadzie Poludniowego Koncernu Weglowego S.A, Zarządzanie Finanse Journal of Management and Finance Vol. 12, No. 1/2014.

Chadam J. (2002), Spółki zależne w polskich grupach kapitałowych - wyniki badań, „Organizacja i Kierowanie".

Dworzecki Z, Mierzejewska W. (2015), Zachowania Polskich grup kapitałowych w czasach kryzysu” Oficyna Wydawnicza Szkoła Główna Handlowa w Warszawie, Warszawa.

Groppelli A. A., Nikbakht E. (1999), Wstęp do finansów, wyd. WIG PRESS, Warszawa.

Pomykalska B., Pomykalski P. (2007), Analiza finansowa przedsiębiorstwa, wyd. PWN, Warszawa.

Kaczmarek B., Glinkowska B. (2012), Tworzenie grup kapitałowych i aliansów strategicznych, Wydawnictwo Uniwersytetu Łódzkiego, Łódź.

Kreft Z. (2004), Holding - grupa kapitałowa, wyd. PWE, Warszawa.

Machała R. (2008), Zarządzanie finansami i wycena firmy, wyd. UNIMEX Oficyna Wydawnicza, Wrocław.

Nowak E.(2009), Analiza sprawozdań finansowych, Polskie Wydawnictwo Ekonomiczne, Warszawa.

Piątek E. (2007), Polityka bilansowa grupy kapitałowej, wyd. CeDeWu, Warszawa. 
Romanowska M. (2002), Trocki M., Wawrzyniak B., Grupy kapitałowe w Polsce, Wydawnictwo Difin, Warszawa.

Sierpińska M., Jachna T. (2004), Ocena przedsiębiorstwa wedtug standardów światowych, wyd. PWN, Warszawa.

Szewc-Rogalska A. (2009), Grupy kapitałowe w gospodarce polskiej [w:] M. G. Woźniak (red.), Nierówności społeczne a wzrost gospodarczy. Problemy globalizacji i regionalizacji, cz. II, Uniwersytet Rzeszowski, Rzeszów 2006.

Szumielewicz W.(2009), Cash management w grupach kapitałowych. wyd. Difin, Warszawa Trocki. M. (2004), Grupy kapitałowe, wyd. PWN, Warszawa.

\title{
MANAGEMENT OF FINANCIAL LIABILITY ON EXAMPLE OF THE CAPITAL GROUP HOTEL INDUSTRY
}

\begin{abstract}
At present, under the conditions of the developing capital market, complex economic structures are becoming increasingly common. Businesses in the market, in order to achieve their goals, enter into numerous and varied relationships with other entities to form capital groups. One of the reasons for this article is to present an image of financial liquidity as disclosed in the consolidated financial statements of enterprise groups. The main objective of the article is to analyze the financial liquidity of a selected capital group in the hotel industry, leading to the isolation of the factors that most affect liquidity.
\end{abstract}

Keywords: financial liquidity, capital group, liquidity ratios 